\title{
Analisis Pemanfaatan Joule Thief Tipe Toroida Pada Sel Volta Menggunakan Elektroda $(C u(A g)-Z n)$ Berbahan Elektrolit
}

\author{
Ahmad Gurum Pauzi and Bela Wicaksana
}

\begin{abstract}
Ringkasan
Pasangan tembaga-seng $(\mathrm{Cu}-\mathrm{Zn})$ merupakan pasangan elektroda yang sering digunakan pada sel volta air laut sebagai sumber energi listrik terbarukan. namun, katoda $C u$ mengalami korosi ketika bereaksi dengan air laut. Oleh karena itu, penelitian ini dilakukan dengan lektroplating $\mathrm{Ag}$ pada $\mathrm{Cu}$, namun karena rendahnya intensitas cahaya yang dihasilkan maka pada penelitian ini digunakan joule thief untuk menaikkan besar energi yang ada dalam keluara sel volta. Pada sistem sel volta ini tersusun dari 20 sel dengan elektrolit air laut serta pasangan elektroda $C u(A g)-Z n$. Elektroda antar sel dihubungkan secara seri dengan kabel penghubung dan air laut diganti setiap 24 jam sekali. Pada sistem ini dilakukan pengukuran massa elektroda dan karakteristik elektrik (tegangan, arus, dan intensitas cahaya) selama 72 jam dengan menggunakan joule thief dan tanpa menggunakan joule thief. Hasil penelitian menunjukkan bahwa sel volta yang menggunakan rangkaian joule thief menghasilkan intensitas cahaya 3 kali lebih besar dibandingkan tanpa penggunaan rangkaian joule thief.
\end{abstract}

Kata Kunci : air laut, $C u(A g)-Z n$, elektroplating, joule thief, sel volta

\begin{abstract}
Copper-zinc pair $(C u-Z n)$ is a pair of electrodes that are often used in sea water voltaic cells as a source of renewable electrical energy. however, the $C u$ cathode experiences corrosion when reacting with seawater. Therefore, this study was conducted by electroplating $\mathrm{Ag}$ on $\mathrm{Cu}$, but due to the low intensity of the light produced, this study used joule thief to increase the amount of energy present in the volume of the voltaic cell. In voltaic cell system composed of 20 cells with sea water electrolytes and $C u(A g)-Z n$ electrode pairs. Inter-cell electrodes are connected in series with connecting cables and sea water is replaced every 24 hours. In this system the measurement of electrode mass and electrical characteristics (voltage, current and light intensity) for 72 hours using joule thief and without using joule thief. The results showed that voltaic cells that use joule thief circuits produce light intensity 3 times greater than without the use of joule thief circuits.
\end{abstract}

Keywords: $C u(A g)-Z n$; electroplating; joule thif; voltaic cell; sea water.

\section{PENDAHULUAN}

Sel volta merupakan sel elektrokimia yang dapat menghasilkan energi listrik akibat terjadinya reaksi redoks secara spontan. Syarat utama sel Volta, yaitu adanya elektroda (anoda dan katoda) dan larutan elektrolit. Air laut merupakan suatu larutan elektrolit yang memiliki kandungan garam natrium klorida $(\mathrm{NaCl})$ yang sangat tinggi. $\mathrm{NaCl}$ ialah suatu garam

\footnotetext{
${ }^{*}$ Correspondence: bellawisana20@gmail.com

Jurusan Fisika, Fakultas Matematika dan Ilmu Pengetahuan Alam, Universitas Lampung, Jl. Prof. Dr. Sumantri Brojonegoro No. 1, 35145,

Bandar Lampung, Indonesia

Full list of author information is available at the end of the article

${ }^{\dagger}$ Equal contributor
}

yang dapat terionisasi secara sempurna menjadi ion $\mathrm{Na}^{+}$dan $\mathrm{Cl}^{-}$. Karena adanya ion bebas tersebut maka menyebabkan air laut dapat menghantarkan arus listrik.

Penelitian tentang kelistrikan elektrokimia merupakan pengembangan hasil penelitian Alexander Volta. Volta memperlihatkan bahwa jika dua buah elektroda dengan beda potensial dimasukan ke dalam larutan elektrolit larutan asam atau garam maka akan dihasilkan energi listrik, karena elektron yang berada pada permukaan anoda akan terlepas dan dibawa oleh ion elektrolit menuju elektroda positif (katoda). Namun permasalahan yang dihadapi yaitu elektroda 
logam yang digunakan akan mengalami korosi yang dapat menyebabkan penurunan mutu dari logam tersebut,berdasarkan deret volta, salah satu logam yang dapat digunakan untuk mengatasi masalah korosi adalah perak $(A g)$ karena memiliki sifat lebih tahan korosi dan konduktivitas yang lebih tinggi dibandingkan $\mathrm{Cu}$, sehingga menggunakan elektroda $C u(A g)-Z n$. Adapun permasalahan lain pada listrik yaitu rendahnya daya penerangan yang dihasilkan, maka untuk memperkuatnya dengan menggunakan Joule thief toroida, untuk menghasilkan penerangan lebih besar pada cahaya lampu

\section{METODE PENELITIAN}

Adapun alat dan bahan dari penelitian ini adalah mesin gerinda, gunting, tang, gelas ukur, lux meter, amperemeter, kertas, pena, spidol, gelas baker, lampu, kabel penghubung, filter air, gallon, kamera, rangkaian joule thief toroida, multimeter, luxmeter, air laut, kayu, pipa PVC, tembaga $(C u)$, larutan $A g$, seng $(Z n)$, lem lilin, kotak penampung, dan selang.

Penelitian dilakukan membuat desain inovasi sistem sel volta elektrolit berbasis air laut menggunakan sepasang elektroda positif dan negatif yang terpasang seri dalam 1 sel sebanyak 20 sel dengan ukuran yang sama, yang terbuat dari elektroda $C u(A g)-Z n$, pada tembaga berserabut yang telah dilapisi larutan perak $(C u(A g))$ dan seng $(Z n)$ yang berbentuk lempengan memiliki luas $18 \mathrm{~cm}$, dengan sistem pengisian ulang elektrolit yang di aplikasikan dengan Joule thief toroida, hal ini bertujuan untuk menghasilkan energi listrik dengan daya yang lebih tinggi secara berkelanjutan dan dapat dikembangkan sebagai energi listrik yang mudah didapatkan. Desain akan dibuat 20 sel dengan sistem tertutup, kemudian elektroda dimasukkan pada sel tersebut dengan volume air laut $\pm 300 \mathrm{ml}$. Air laut diganti setiap 24 jam sekali yang dilakukan selama 72 jam dan diambil data sekali dalam satu jam, dengan menggunakan Joule thief dan tanpa Joule thief. Setelah alat terbentuk, maka akan dilakukan pengambilan data karakteristik energi listrik yang dihasilkan oleh alat. Beban yang digunakan adalah rangkaian LED dengan daya maksimum 3 Watt 12 Volt yang menggunakan hambatan tertentu. Adapun desain sel volta seperti pada Gambar 1.

Salah satu metode mengubah air laut menjadi listrik adalah elektrokimia. Penelitian tentang kelistrikan elektrokimia merupakan pengembangan hasil penelitian Alexander Volta. Volta memperlihatkan bahwa jika dua buah elektroda dengan beda potensial dimasukan ke dalam larutan elektrolit larutan asam atau garam maka akan dihasilkan energi listrik, karena elektron yang berada pada permukaan anoda akan terlepas dan dibawa oleh ion elektrolit menuju

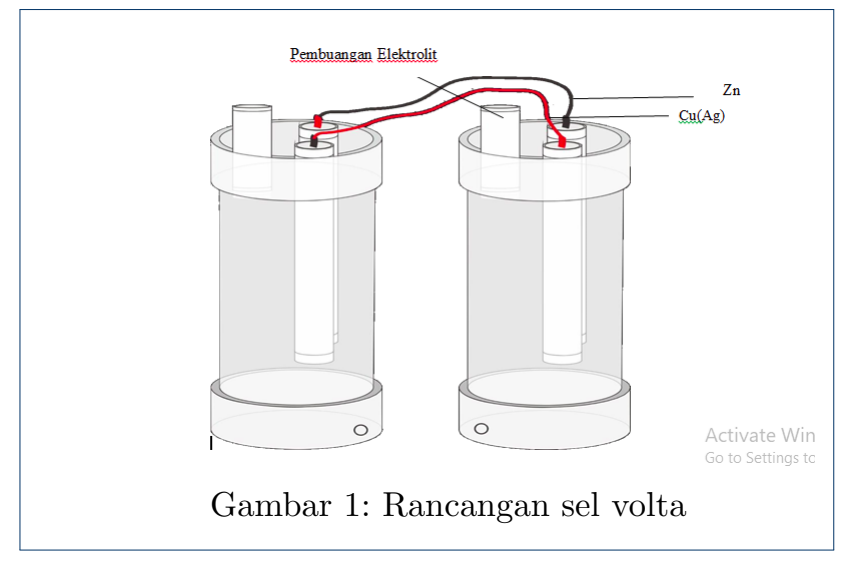

elektroda positif (katoda). Namun permasalahan yang dihadapi yaitu elektroda logam yang digunakan akan mengalami korosi yang dapat menyebabkan penurunan mutu dari logam tersebut [1].

Pelapisan $\mathrm{Cu}$ dilakukan proses elektroplating $\mathrm{Ag}$ pada $\mathrm{Cu}$ sebanyak $300 \mathrm{ml}$ sebagai larutan elektrolitnya. $\mathrm{Cu}$ sebagai katoda dan batang karbon sebagai anoda. Sebelum dilakukan elektroplating, permukaan logam $\mathrm{Cu}$ dibersihkan dengan larutan $\mathrm{HNO}_{3} \quad 1 \%$ untuk mengurangi kandungan lemak yang menempel pada $C u$. Kemudian permukaan logam $\mathrm{Cu}$ tersebut dibersihkan kembali dengan alkohol $70 \%$. Selanjutnya, elektroplating dilakukan dengan tegangan sebesar 3 volt selama 3 menit. Pada penelitian ini dilakukan pengambilan data secara manual untuk nilai karakteristik elektrik, yaitu tegangan saat tanpa beban $\left(V_{t b}\right)$, tegangan saat beban dipasang $\left(V_{b}\right)$, arus $(I)$, dan intensitas cahaya $(l u x)$.

\section{HASIL DAN PEMBAHASAN}

\section{A. Realisasi alat}

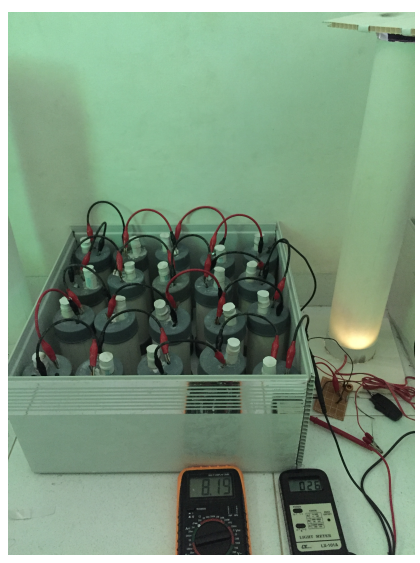

Gambar 2: Rangkaian sel volta 


\section{B. Hasil Penelitian}

Pada penelitian ini menggunakan elektroda $\mathrm{Cu}(\mathrm{Ag})$ sebagai katoda, $Z n$ sebagai anoda, dan air laut dijadikan sebagai elektrolit. Pada penelitian ini digunakan $\mathrm{Cu}(\mathrm{Ag})$ berbentuk serabut 25 helai yang bermassa rata-rata $4,504 \mathrm{gram}$ dan $Z n$ berbentuk lempengan dengan massa 4,649 gram.

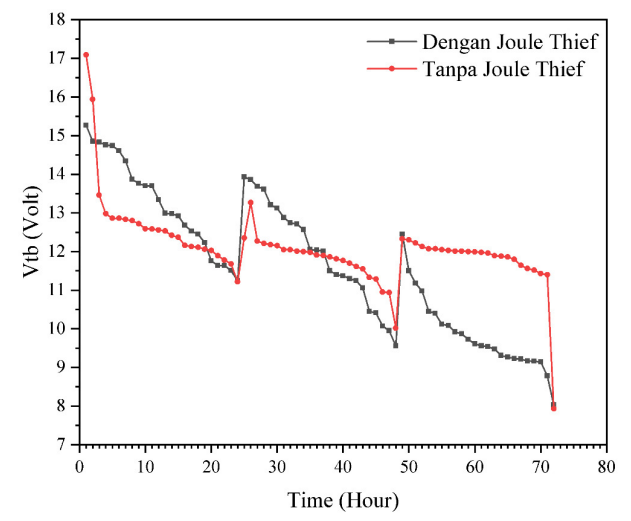

Gambar 3: Hubungan $V_{t b}$ dengan waktu

Nilai tanpa menggunakan Joule Thief $V_{t b}$ pada satu jam pertama (maksimum) yang dihasilkan $C u(A g)-Z n$ adalah 17,09 Volt dan pada jam ke 24 mengalami nilai minimum yaitu $11,22 \mathrm{Volt}$, sedangkan setelah pengisian elektrolit ulang diperoleh nilai $V_{t b}$ maksimum pada jam ke-25 yaitu 12,35 Volt hal ini karena setelah mengalami pengisian elektrolit lama maka terdapat hambatan dalam dan korosi juga sedikit menghambat akan besarnya tegangan, penelitian ini sesuai dengan penelitian terkait yaitu (Anwar dan Suci, 2013).

Nilai tersebut menunjukkan bahwa nilai $V_{t b}$ tanpa Joule Thief yang pertama dihasilkan lebih tinggi daripada dengan Joule Thief, tapi pada nilai selanjutnya lebih konstan dan bahkan lebih tinggi dengan menggunakan Joule Thief, hal ini juga disebabkan karena rangkaian joule thief cepat bereaksi sehingga tegangan lebih cepat menurun, dan adanya electrical double layer, ketika elektrolit didiamkan lebih lama maka akan semakin rata dan mengakibatkan arus listrik semakin menurun.

Penelitian tanpa menggunakan Joule Thief menunjukkan nilai $I$ pada satu jam pertama yang dihasilkan $C u(A g)-Z n$ adalah 8, $6 m A$, dan pada hasil terendah pengisian elektrolit hari pertama yaitu pada jam 24 yaitu $3,04 m A$. Kemudian pada percobaan dengan menggunakan Joule Thief menunjukkan nilai $I$ pada satu jam pertama yang dihasilkan $C u(A g)-Z n$

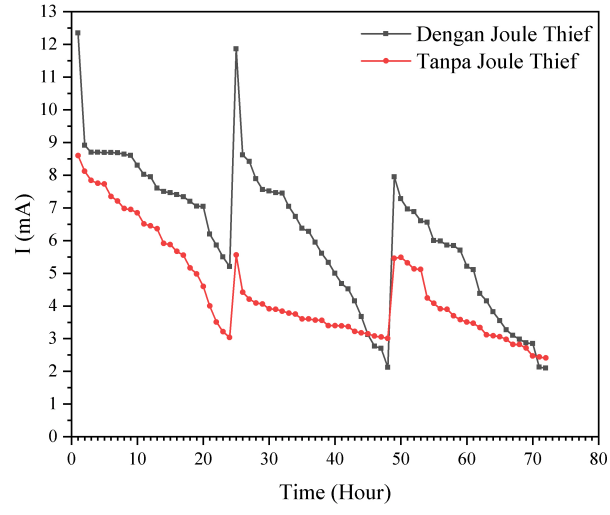

Gambar 4: Hubungan arus dengan waktu

adalah $11,35 m A$, dan pada hasil terendah pengisian elektrolit hari pertama yaitu pada jam 24 yaitu $5,2 m A$.

Dari hasil tersebut diketahui bahwa nilai arus dengan menggunakan Joule Thief lebih besar daripada tanpa menggunakan Joule Thief, dan arus yang dihasilkan berbanding lurus dengan nilai $V\left(V_{b}\right)$. Semakin besar nilai $V_{b}$ yang dihasilkan maka semakin besar muatan listrik yang dapat dipindahkan sehingga I yang dihasilkan semakin besar pula Dari penelitian ini terbukti bahwa rangkaian Joule Thief dapat memberikan penguatan arus [2].

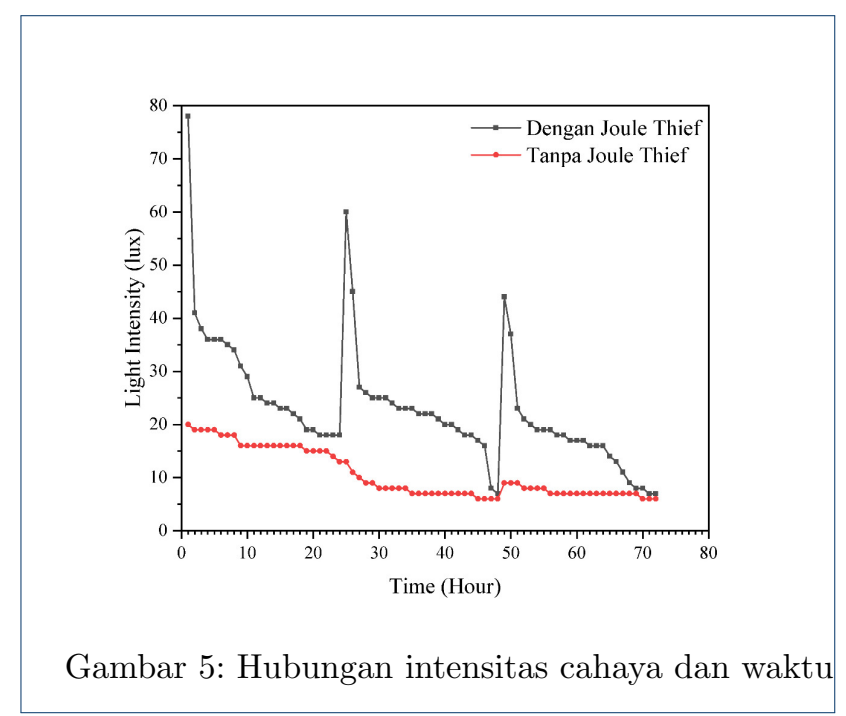

Dari nilai tersebut dapat diperlihatkan bahwa nilai intensitas cahaya dengan menggunakan Joule Thief mendapatkan hasil 3 kali lebih terang. Kemudian semakin besar nilai $I$ maka nilai intensitas cahaya yang dihasilkan juga semakin besar. Berdasarkan 
nilai $V_{t b}, V_{b}$, dan $I$ terhadap waktu dapat dilakukan perhitungan untuk mencari nilai daya $(P)$.

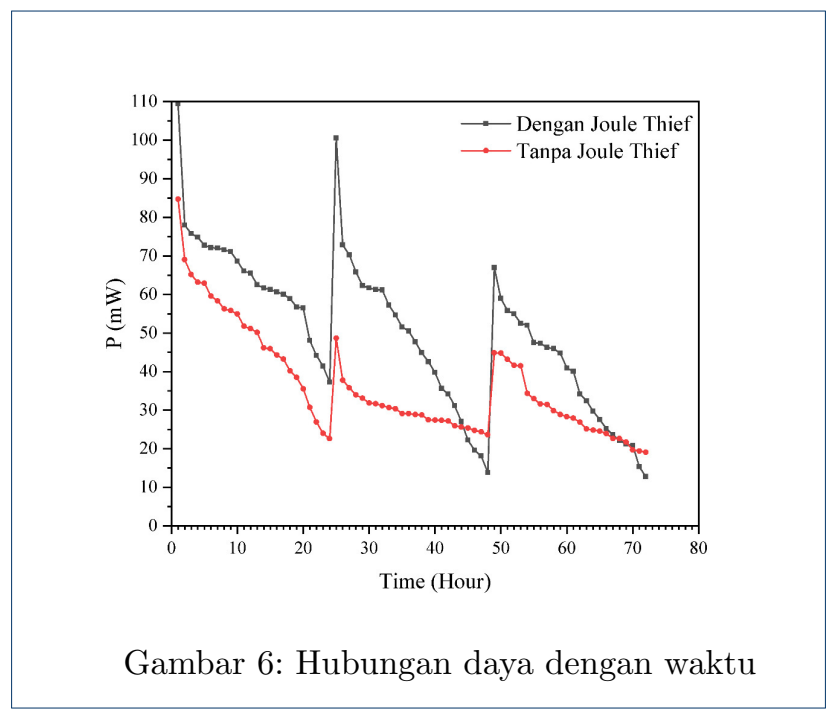

Setiap pergantian elektrolit baru maka nilai besar, kemudian menurun dan keadaan itu terjadi karena nilai $P$ merupakan hasil perkalian antara nilai $V_{b}$ dan $I$ yang dihasilkan sehingga jika nilai $V_{b}$ dan $I$ semakin besar maka nilai $P$ semakin besar pula dan begitu sebaliknya, semakin kecil nilai $I$ maka akan semakin kecil nilai $P$, hal tersebut karena adanya korosi pada elektroda dan berkurangnya konsentrasi air laut yang menyebabkan berkurangnya energi listrik yang dihasilkan [3]. Pada penelitian ini joule thief berfungsi untuk menaikkan dan memperkuat arus, bukan untuk meningkatan tegangan, sehingga diperoleh intensitas cahaya yang semakin tinggi karena nilai arus dan nilai intesnsitas cahaya berbanding lurus, semakin tinggi arus listrik maka akan semakin besar intensitas cahaya yang diperoleh.

\section{KESIMPULAN}

Adapun kesimpulan dari penelitian ini yaitu keluaran yang dihasilkan dalam implementasi Joule Thief toroida dengan daya input rendah mendapatkan intensitas cahaya tiga kali lebih besar daripada tanpa menggunakan Joule Thief, dan keluaran yang dihasilkan pada pengisian ulang elektrolit tanpa Joule Thief menghasilkan keluaran lebih konstan..

\section{PENULIS}

1 Ahmad Gurum Pauzi

Dari :

(1) Jurusan Fisika, Fakultas Matematika dan Ilmu Pengetahuan Alam, Universitas Lampung
2 Bela Wicaksana

Dari :

(1) Jurusan Fisika, Fakultas Matematika dan Ilmu Pengetahuan Alam, Universitas Lampung

Pustaka

1. Pauzi GA, Hudaya E, Supriyyanto A, Warsito. Analisis Uji Karakteristik Elektrik Air Laut sebagai Sumber Energi Listrik Terbarukan. In: Proseding SN SMIAP. Universitas Lampung; 2016. .

2. Anwar M, Suci R. Joule Thief Sebagai Boost Converter Daya LED Menggunakan Sel Volta Berbasis Air Laut. J Al-Azha Indones Seri Sains dan Teknol. 2017;4(2).

3. Rizki KC. Analisis Pengaruh Elektroplating Perak (Ag) pada Tembaga (Cu) Terhadap Karakteristik Elektrik Air Laut sebagai Sumber Energi Listrik Terbarukan [Skripsi]. Universitas Lampung; 2019. 